\title{
Instilling Civic Disposition Values through Scouting Activities at SMP PAB 9 Klambir Lima Kebun, Deli Serdang
}

\author{
Windawati Pinem ${ }^{1)}$, Jamaludin ${ }^{2)}$, Muhammad Iqbal ${ }^{3)}$, Mazwin Lincah ${ }^{4)}$ \\ Department of Pancasila and Citizenship Education, Universitas Negeri Medan, Indonesia ${ }^{1,2)}$ \\ Study Program of Anthropology Education,Universitas Negeri Medan, Indonesia ${ }^{3)}$ \\ Study program of Pancasila and Citizenship Education, Universitas Muhammadiyah Sumatera Utara \\ Universitas Negeri Medan, Indonesia ${ }^{4}$ \\ windawatipinem@unimed.ac.id ${ }^{1)}$, jamaludin@ @unimed.ac.id ${ }^{2)}$, iqbal81@ @unimed.ac.id ${ }^{3)}$
}

\begin{abstract}
The research objective was to analyze how scouting activities in extracurricular programs in junior high schools in instilling civic disposition values, in this case the application of citizen character can be implanted through scouting activities, therefore this study focuses on students who are actively involved in scouting activities. This research method is qualitative using case studies which are the object of research are 10 students, school principals, and scout coaches, the results and conclusions of this research are that every scout activity always uses educational elements, implements a simple lifestyle and a pamong system with scout coaches through expertise. exemplary and civic disposition values from extracurricular activities through scouting activities, there are values of responsibility, discipline, love for the motherland and the environment, tolerance, friendship, honesty, independence, creativity, religion, environmental care and social care.
\end{abstract}

Keywords: Extracurricular, Scouting, Civic Disposition

\begin{abstract}
Abstrak. Tujuan penelitian untuk menganalisis bagaimana kegiatan pramuka pada program ektrakurikuler di sekolah tingkat menengah pertama dalam menanamkan nilai civic disposition, dalam hal ini penerapan watak warganegara apakah dapat ditanamkan melalui kegiatan pramuka, maka dari itu penelitian ini fokus kepada siswa yang terlibat aktif dalam kegiatan kepramukaan. Metode penelitian ini kualitatif dengan menggunakan studi kasus yang menjadi objek penelitiannya adalah 10 orang siswa, kepala sekolah, dan pembina pramuka, hasil dan simpulan penelitian ini yaitu setiap kegiatan pramuka selalu menggunakan unsur pendidikan, menerapkan pola hidup sederhana dan sistem pamong dengan Pembina pramuka melalui kepiawaian teladan dan nilai-nilai Civic disposition dari kegiatan ekstrakurikuler melalui aktivitas pramuka terdapat nilai tanggung jawab, disiplin, cinta tanah air dan lingkungan, toleransi, bersahabat, jujur, mandiri, kreatif, religius, peduli lingkungan dan peduli sosial
\end{abstract}

Kata Kunci: Ekstrakurikuler, Pramuka, Civic Disposition. 


\section{INTRODUCTION}

Educational goals listed in Law no. 20 of 2003 concerning the National Education System article 3 explains that national education functions to develop capabilities and shape the character and civilization of a nation with dignity in the framework of educating the nation's life, aiming at developing the potential of students to become human beings who believe and fear God Almighty, with character noble, healthy, knowledgeable, capable, creative, independent and become democratic and responsible citizens. Therefore, Citizenship Education is a subject that focuses on self-formation as a character or personality in various students. This diversity can be seen from the aspects of religion, culture, sociocultural, language, age and ethnicity which lead to the creation of smart, civilized and characterized citizens according to the mandate of Pancasila and the 1945 Constitution (Dianti, 2014).

The character or personality of students can be proclaimed through aspects of moral values, in the delivery of education, it can be seen through curricular programs that are integrated with civic education subjects. The values contained in civic education are the values of religiosity, honesty, intelligence, toughness, caring, democratic, nationalist, obedience to social rules, respect for diversity, awareness of the rights and obligations of oneself and others. These values must be possessed by students to become good and smart citizens.

Citizenship Education (Civics) is one of the fields of study that carries out a national mission to educate the lives of the Indonesian nation through the corridor of "value-based education" Civics is designed as a learning subject that aims to develop the individual potential to become Indonesian citizens with noble, intelligent, participatory, and noble character. responsible (Narimo et al., 2018). In the cognitive, affective, and psychomotor dimensions which are confluent or mutually penetrating and integrated with the context of the substance of the ideas, values, concepts and moral of Pancasila, democratic citizenship, and state defence (Damri et al., 2020).

It can be interpreted that civic education has a major role to produce good citizens in the life of the nation and state. According to Branson, civic education is divided into three parts, namely civic knowledge, civic skills, and civic disposition. Why is civic education in schools important for the nation? A distinctive civic education orientation has been known since the early days of the Republic, the formation of a welldeveloped political institution is not in itself a sufficiently strong foundation for maintaining constitutional democracy. They know that ultimately a free society must depend on its citizens for their knowledge and skills and their morals and civic virtues. They believe that the mission of civic education in schools 
is to develop the qualities of mind and heart that successful governance in a constitutional democracy requires (Branson \& Quigley, 1998).

Civic knowledge is something that is related to what content or value citizens should know. This aspect concerns scientific academic skills developed from various theories or concepts of politics, law, and morals. Meanwhile, the Civic Disposition is the characteristics of citizenship, which implies the public and private character which is important for the maintenance and development of constitutional democracy (Galston, 2007).

In substance, Civics lessons are science content which consists of multidisciplinary fields of study (Muchtarom, 2012). The content contained includes the material related to Citizenship knowledge about the rights and responsibilities of citizens, human rights, democratic principles and processes, government institutions and nongovernmental institutions, national identity, rule of law and free and unlawful judiciary. taking sides, the constitution, and the values and norms in society (Nurdin, 2016).

In the area of civics, the most substantive and essential dimensions of Civics are seen as the "estuary" of the development of the two previous dimensions. By paying attention to the vision, mission, and objectives of Civics subjects, the characteristics of these subjects are characterized by an emphasis on the dimensions of character, character, attitudes and other potentials that are affective (Lestari, 2016).

Character is divided into 2 as follows:

"Private characters such as moral responsibility, self-discipline and respect for the human dignity of each individual are mandatory. And the character of the public is a concern as citizens, politeness, heeding the rules of the game (rule of law), critical thinking, and a willingness to listen, negotiate and compromise is characteristics that are indispensable for a successful democracy to run".

Private character is more of an assessment of yourself or individuals. This assessment is seen from the good attitude and ethics and reflects the attitude of responsibility, religion, care, and tolerance. In addition, the private character can also be seen from their attitude of respecting the time and respecting other humans. Meanwhile, the public character is more directed towards good behaviour towards the state and as citizens. For example, being democratic and following all the rules that apply in the country and not violating any of these rules (Budimansyah, 2008).

The educational process is known as two elementary activities, namely extracurricular activities and extracurricular activities. Extracurricular activities are generally preferred activities of choice by students. In this activity, it is very appropriate 
if the basic cultural values of the nation are integrated.

With the implementation of various changes to the education curriculum from 2006 to the latest through the 2013 Curriculum, it is the spirit of manifesting the improvement of the education system in Indonesia so that it can produce a generation of quality and character. This commitment can be interpreted as a component of the 2013 Curriculum which includes Scouting education as a compulsory extracurricular activity in schools. The inclusion of Scouts in the 2013 Curriculum is a vehicle for the formation of student character (affective). Scouting activities are expected to shape the character and personality of the nation's children.

The scout or scouting movement was formulated by its founders as a medium to improve the character of children and adolescents, as well as train them to be responsible and independent when they grow up. The emergence of various problems and challenges faced by students, for example, problems and challenges of nationality, especially those related to changes in the values of social and cultural life (Rizky, 2012).

Scouting education is very important for students for self-development in schools, who are going through a transition period of looking for an identity, and still do not have a permanent stand. Because most students in junior high and high school still do not have an identity and identity and are often easily influenced by things that cause moral degradation with various negative behavioural acts (Muhaemin \& Ihwah, 2019). In the influence of the era of globalization and the era of digital information which influences the style and behaviour of students, scouting education is considered very important for student self-development. Because so far most students do not have an identity, and many negative actions have been committed, for example skipping school and engaging in brawls, fights that have even claimed lives. Most students in schools are affected by bad influences in the environment, this is because most students do not yet have a personality and principles and identity that are fixed and firm. Scouting education not only makes students more character and has principles, skills, has an independent spirit, has a leadership spirit and a positive personality. Scouts also teach students how to recognize the environment and survive in emergencies, various knowledge and survive in emergencies, various knowledge and survival sciences such as using various objects in the natural surroundings, which will make students more resilient and love the nature around them.

By providing scouting education in schools, students will have more character, responsibility, independence, have leadership and positive moral behavior and can give birth to students who are physically and morally strong (Damanik, 2014). Referring to the 
Indonesian Minister of Education and Culture Regulation Number 81A of 2013 concerning the Implementation of the 2013 Curriculum, attachment III explains that the function of Scout extracurricular activities is that extracurricular activities in educational units have a development, social, recreational, and career preparation function, namely. First; the development function, namely that extracurricular activities function to support the personal development of students through expanding interests, developing potential, and providing opportunities for character building and leadership training. Second; social function, namely that extracurricular activities function to develop the abilities and sense of social responsibility of students. Social competence is developed by providing opportunities for students to expand social experiences, practice social skills, and internalize moral and social values. Third; recreational function, namely that extracurricular activities are carried out in a relaxed, joyful, and fun atmosphere so as to support the development process of students. Extracurricular activities must be able to make school life or atmosphere more challenging and more attractive to students. Fourth; career preparation function, namely that extracurricular activities function to develop students' career readiness through capacity building.

\section{RESEARCH METHODS}

This study used qualitative research methods. Qualitative research is a method for exploring and understanding the meaning that several individuals or groups of people think comes from a social or humanitarian problem (Creswell \& Creswell, 2017). This qualitative research process involved important efforts, such as asking questions and procedures, gathering specific data from participants, analyzing data inductively from specific themes to general themes, and interpreting the meaning of the data. The shirt study method was chosen in this research because the problems to be studied occur in certain places and situations. Qualitative research using the case study method was intended for realities that occur in the field as they are (Neuman, 2016).

As for the objects in this study were 10 students, school principals, and scout coaches at SMP PAB 9 Klambir Lima Kebun for the 2019-2020 academic year. The data analysis technique was divided into 3 components, namely: Data Reduction, Data Presentation and Verification or Conclusions.

\section{DISCUSSION}

The scout coaches at SMP PAB 9 Klambir Lima Kebun for the 2019-2020 academic year become a youth organization oriented towards national service. Scouting is a fun game in the open world, where children and adults go together to develop health and 
happiness, skill and willingness to help those in need.

Education organized by the Boy Scout movement is essentially non-formal education. This means that this education is carried out outside of school education and outside of family education. Even so, the education organized by the Scout Movement is very supportive of education in the school environment and in the family environment. Call it education which is closely related to discipline, then isolation, brotherhood, as well as service to society and character formation. All of that can be obtained from scouting activities.

Character or character is divided into 2 as follows: Private characters such as moral responsibility, self-discipline and respect for the human dignity of each individual are mandatory. And the character of the public is a concern as citizens, politeness, heeding the rules of the game (rule of law), critical thinking, and willingness to listen, negotiate and compromise are characteristics that are indispensable for a successful democracy.

Private character is more of an assessment of yourself or individuals. This assessment is seen from a good attitude and ethics and reflects an attitude of responsibility. Also, the private character can also be seen from the attitude of respecting the time and respecting other humans. Meanwhile, the public character is more directed towards good behaviour towards the state and as citizens. For example, following all the rules that apply in the country and not violating any of these rules.

The findings in the implementation of scouting activities at SMP PAB 9 Klambir Lima Kebun for the 2019-2020 academic year, namely line activities or $\mathrm{PBB}$, this is an example of private character, where each participant's actions will be assessed as disciplined in marching and responsible for making the right movements as ordered. Meanwhile, the public character can be found at the campfire. In this activity, each team will discuss to present the best offerings to the coach as a closing activity. Besides, participants were also taught to listen to the guidance of the coach's brother in carrying out campfire activities, starting from being the host of the show to the process of reciting Dasa darma.

Observations made by researchers examined how attitudes and behaviours are obedient, respectful and respectful of the values of tolerance in carrying out the teachings of their religion, are tolerant of the implementation of the worship of other religions and live in harmony with followers of other religions. It was emphasized that the results of interviews from participants or informants, before conducting scouting activities, the coach always gave orders to pray together led by a friend. Praying together is carried out before carrying out extracurricular activities and usually, the prayer leaders are 
carried out alternately, meaning that each extracurricular participant must have a turn to lead the prayer.

The spiritual value and the value of tolerance appear before doing the scouting activities, the enforcers pray together to ask for the smooth running of the greetings they live. Every activity takes place and the voice of the call to prayer is heard, then the coach orders to stop all activities and perform ablution and then pray in touch. The embodiment of private and public character by directly practising how religious orders are one of the important instruments in scouting activities. For example, running worship when the activity is in progress when it is prayer time. Then the value of tolerance and care must be implemented with ethics (greetings, smiles, politeness, greetings and smiles). In scouting it is recommended to do $5 \mathrm{~S}$ and not only in scouting, but $5 \mathrm{~S}$ is also done outside of scout extracurricular activities or in community life.

Then scout activities in instilling a character of honesty through doing work based on their authority, committing to maintaining and expressing the truth. In UN activities, it can form a more responsible person. Where is the practice of the tenth dasa darma "Pure in thought, word and deed". It means that in scouting, it is taught to always be honest in any matter and to be attached to the scout's activities only but to behave honestly at all times. Practicing honesty is very applied in every activity, not only in scout extracurricular activities but when outside of scout extracurricular activities.

A student can be said to have a caring character, including that students can maintain cleanliness, beauty, and preservation of nature; students can share and participate in assisting according to their ability to others who are hit by disaster or less fortunate in their lives; students are not passive (not indifferent) but proactive with changes in environmental conditions. Scouting activities are very related to nature, so every time the activity is completed, the enforcers are assigned to quote and clean up the garbage in the surrounding environment. Keeping the environment clean is a task that enforcers and participants do at all times to keep the environment clean. And instilling nature is part of the life of the scouts themselves.

A caring attitude is also one of the good behaviors applied in scouting. Help each other and help each other when a sick friend is shown when LBB activities are carried out. The enforcers will readily help their friends who are sick, then carry them to the available tents or posts. So the hope is that the scout participants later in applying the values of scouting can be said to have a character by having a personality, caring, discipline, responsibility, for example doing assignments independently or collaborating according to teacher orders and on time; dare to take risks for what has been done; carry out their duties and obligations by the stipulated time; have the 
willingness to be willing to apologize for wrongdoing others and promise not to repeat; willing to be given sanctions for violations that have been committed.

The character of responsibility is built through a scout team approach where the chairman and participants have their respective responsibilities and duties. The chairman is responsible for conditioning each member. And team members are responsible for following every word or direction of the team leader. That way, the team you have will have good cohesiveness. Then the attitude of responsibility is trained through discipline and on time. Respect for time is an attitude of responsibility that is closest to everyday life. And the person who can appreciate the time must be someone who has a lot of responsibility.

Among the democratic characters, students respect the opinions and rights of others; does not impose will on others; carry out deliberation in making decisions; strive for deliberation to reach consensus; students accept and implement the results of deliberation decisions as they should; students take an active role in overcoming public problems (including being active in school activities, providing constructive criticism in making classroom rules, school regulations, village regulations and other regulations).

Democratic values through deliberation and consensus approaches are always the best way when there are problems that must be resolved by each team. By way of deliberation, all kinds of decisions are taken calmly and there is no disturbance. Decisions taken are decisions of collective thought or deliberation. In other words, holding a deliberation will minimize the possibility of a dispute between the team leader and team members. It was not just the selfish thoughts of the team leader. Therefore conducting deliberation is something the team leader takes to make a joint decision. A student can be said to have this character, namely students have an attitude of mutual respect and respect in building an attitude of cooperation; does not discriminate against friends of any background; respect the work or products of other tribes, by giving an appreciation, collecting, wearing, or singing.

Characters respect and respect each other or embodiment of the motto "Bhineka Tunggal Ika". Can be interpreted in the scouting activities at SMP PAB 9. The differences do not become a barrier to brotherhood and friendship between participants, by not disturbing when they are worshiping, not criticizing other religions, appreciating differences, being aware of differences, are the necessities of God as beauty and strength. So mutual respect and respect for any religious differences that exist around them is a commendable attitude taught in scouts.

Scouting education at SMP PAB has received dialogue from scout coaches, namely 
using Law no. 10 of 2013 concerning scouting statutes and bylaws. So all activities carried out in this SMP are based on this law. For example, the activities we do are 8 scouting methods, one of which is learning by doing. So before we carry out activities in the field, we first give theories to the students in the class then we go to the field.

The scouts are TRISATYA and DASA DARMA oriented to the values of Pancasila. Routine activities carried out on Fridays and Saturdays such as LBB at school, PERSAMI (Camp of Saturday Sunday) and monthly activities from KWARAN Hamparan Perak and KUARTIR activities at the Deli Serdang branch. Of course this is not easy to instill private and public characters, it requires the cooperation of several related parties, for example schools, families and the environment who play an active role. The three instruments that play a role must go hand in hand in guarding the process of cultivating this character and strengthening must be carried out in this scouting activity.

The big hope from this Scouting activity is that it will be able to change the mindset of children and teach them to be more independent and cooperate with a sense of togetherness and responsibility. Although this dominant role is in the ranks of the coaches because they are role models or models in instilling and strengthening the character values that exist in scout extracurricular activities. Direct involvement trains participants and plays an important role in building the character or personality of the participants.

\section{CONCLUSION}

Based on the results of research in the field obtained through observation, questions and answers or interviews, the researcher can conclude that the implementation of scout extracurricular activities in character building for students of SMP PAB 9 Klambir Lima Kebun has been carried out well. The implementation of the activities is divided into 2 activities, namely weekly training every Friday and Saturday and monthly activities, namely PERSAMI which is accompanied by the coach. Scout activities in SMP PAB use a team system and a separate unit system. In each of their activities, scouts always use educational elements that are oriented towards instilling the values of Pancasila through Law no. 10 of 2013 concerning scouting statutes and bylaws. So all activities carried out in this SMP are based on 8 scouting methods, one of which is learning by doing. So before we carry out activities in the field, we first give theories to the students in the class then we go to the field. The hands of this scout are TRISATYA and DASA DARMA, applying a simple lifestyle and with a system among, with the coach as the guardian. Civic disposition values from scouting extracurricular activities are responsibility, discipline, love for the country and the environment, tolerance, friendship, 
honesty, independence, creativity, religion, environmental care and social care.

\section{REFERENCES}

[1] Branson, M. S., \& Quigley, C. N. (1998). The role of civic education.

[2] Budimansyah, D. (2008). PKn dan masyarakat multikultural. Program Studi Pendidikan Kewarganegaraan, Sekolah Pascasarjana, Universitas

[3] Creswell, J. W., \& Creswell, J. D. (2017). Research design: Qualitative, quantitative, and mixed methods approaches. Sage publications.

[4] Damanik, S. A. (2014). Pramuka ekstrakurikuler wajib di sekolah. Jurnal Ilmu Keolahragaan, 13(02), 16-21.

[5] Damri, M. P., Putra, F. E., \& Kom, M. I. (2020). Pendidikan kewarganegaraan. Prenada Media.

[6] Dianti, P. (2014). Integrasi Pendidikan Karakter dalam pembelajaran Pendidikan Kewarganegaraan untuk mengembangkan karakter siswa. Jurnal Pendidikan Ilmu Sosial, 23(1).

[7] Galston, W. A. (2007). Civic knowledge, civic education, and civic engagement: A summary of recent research. International Journal of Public Administration, 30(6-7), 623-642.

[8] Lestari, R. Y. (2016). Peran Kegiatan Ekstrakurikuler Dalam Mengembangkan Watak Kewarganegaraan Peserta Didik. Untirta Civic Education Journal, 1(2).

[1] Muchtarom, M. (2012). Strategi penguatan nilai-nilai Pancasila melalui inovasi pembelajaran $\mathrm{PKn}$ berorientasi civic knowledge, civic disposition, dan civic skill di perguruan tinggi. Pkn Progresif, 7(2), 158897.

[9] Muhaemin, M., \& Ihwah, A. (2019). Pengaruh Pendidikan Pramuka Terhadap Pembentukan Karakter Religius pada Anggota Pramuka. Al-Iltizam: Jurnal Pendidikan Agama Islam, 4(1), 111-120.
[10] Narimo, S., Maryadi, M., Fatoni, A., Anif, S., Sumardjoko, B., \& Adhantoro, M. S. (2018). Pancasila and Citizens Education (PKn) Learning Based on Local Culture in The Establishment of Student Characters. Profunedu International Conference Proceeding, 1, 255-260.

[11] Neuman, W. L. (2016). Understanding research. Pearson.

[12] Nurdin, E. S. (2016). Analisis Konten Dimensi Implementasi Kebijakan Publik pada Konten Kurikulum Pendidikan Kewarganegaraan di Perguruan Tinggi. SOSIOHUMANIKA, 9(1).

[13] Rizky, K. S. (2012). Mengenal Dunia Pramuka Indonesia. Galangpress Publisher.

[14] Suardi, S., Herdiansyah, H., Ramlan, H., \& Mutiara, I. A. (2019). Implementasi Pendidikan Karakter Melalui Mata Pelajaran Pendidikan Kewarganegaraan di SMA Jaya Negara Makassar. JED (Journal of Etika Demokrasi), 4(1).

[15] Zuriati, E. (2019). Internalisasi Nilai-Nilai Karakter dalam Pembelajaran Matematika Melalui Model Pembelajaran Think Pair Share (TPS). JED (Journal of Etika Demokrasi), 4(1). 